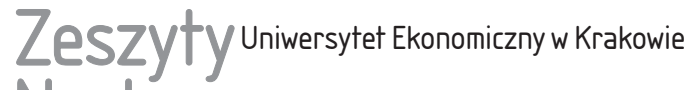 Naukowe
}

$10(934)$

ISSN 1898-6447

Zesz. Nauk. UEK, 2014; 10 (934): 5-17 DOI: 10.15678/ZNUEK.2014.0934.1001

Krzysztof Jackowicz

Katedra Bankowości i Ubezpieczeń

Akademia Leona Koźmińskiego

Oskar Kowalewski

Instytut Nauk Ekonomicznych PAN

Łukasz Kozłowski

Katedra Bankowości i Ubezpieczeń

Akademia Leona Koźmińskiego

\section{Charakterystyki rynków lokalnych a decyzje banków dotyczące sieci placówek}

\section{Streszczenie}

Celem artykułu jest odpowiedź na pytanie, w jaki sposób charakterystyki ekonomiczne rynków lokalnych wpływają na decyzje polskich banków dotyczące ich sieci placówek. Na podstawie danych z lat 2007-2013 ustalono, że gęstość sieci placówek jest największa na terenach bogatych i zurbanizowanych. Tempo wzrostu liczby placówek jest jednak większe tam, gdzie dotychczas gęstość sieci była niższa. Pozytywnie zarówno na gęstość sieci, jak i tempo jej rozwoju wpływa aktywność ekonomiczna ludności.

Słowa kluczowe: rynki lokalne, sieci placówek, konkurencja, banki.

\section{Wprowadzenie}

Decyzje banków dotyczące tworzenia i zamykania placówek bankowych mają znaczenie nie tylko dla ich kondycji finansowej i sytuacji konkurencyjnej na rynku 
lokalnym, ale także dla przedsiębiorstw i gospodarstw domowych na danym terenie. Niebagatelność tego wpływu dokumentuje wiele badań przeprowadzonych na rynkach rozwiniętych (np. [Zarutskie 2006, Huang 2008, Ho i Ishii 2011]). Prezentowany krótki artykuł wpisuje się w nurt dociekań nad determinantami decyzji dotyczących placówek bankowych. Koncentruje się przy tym na specyficznym typie przesłanek tego rodzaju decyzji, a mianowicie cechach rynków lokalnych. Zestawienie bazy danych o placówkach polskich banków komercyjnych, spółdzielczych i tzw. SKOK-ów z cechami socjoekonomicznymi powiatów udostępnianymi przez Główny Urząd Statystyczny pozwoliło na ustalenie, że zagęszczenie placówek jest, zgodnie z oczekiwaniami, największe na terenach bogatych i zurbanizowanych oraz że jednocześnie najszybszy wzrost liczby placówek obserwowano w powiatach biedniejszych i tam, gdzie gęstość sieci była w przeszłości relatywnie mniejsza. Ocena zidentyfikowanych tendencji nie jest jednoznaczna. Badania objęły lata 2007-2013, a więc okres spowolnienia gospodarczego. Analiza zachowań banków w tego rodzaju warunkach jest szczególnie interesująca. M. Kim i B. Vale [2001] na podstawie danych z lat 1988-1995 z Norwegii wykazali, że kryzys zmienia strategiczne zachowania banków, uczulając je na potencjalne, odwetowe reakcje konkurentów na decyzje dotyczące rozbudowy własnej sieci.

Dalsza część artykułu składa się z 5 punktów. W punkcie 2 dokonano przeglądu literatury przedmiotu. Punkty 3 i 4 przynoszą odpowiednio sformułowanie hipotez badawczych oraz omówienie metody badawczej i wykorzystanego zestawu badań. Wyniki estymacji modeli zaprezentowano w punkcie 5 . W podsumowującym punkcie 6 przypomnieliśmy najważniejsze ustalenia oraz wskazaliśmy na potencjalnie niejednoznaczne skutki zaobserwowanych tendencji.

\section{Przegląd literatury przedmiotu}

Z uwagi na bogatą literaturę przedmiotu dotyczącą placówek bankowych i ich sieci do omówienia wybrano z jednej strony prace o największym znaczeniu dla interpretacji naszych wyników, z drugiej zaś nowsze publikacje, w których testowano hipotezy we współczesnych realiach instytucjonalnych i technicznych. Pod względem przedmiotu badań istniejący dorobek literatury można podzielić zdaniem autorów niniejszej publikacji na cztery główne nurty rozpatrujące oddziaływanie decyzji dotyczących placówek lub zmian regulacyjnych odnoszących się do tworzenia sieci odpowiednio na: procesy wzrostu gospodarczego, dostęp do kredytu bankowego, ryzyko i kondycję banków oraz sytuację konsumentów i deponentów. W klasyfikacji tej pominięto bardzo obszerną grupę badań nad sposobami pomiaru efektywności działania poszczególnych placówek. Literatura z interesującego nas obszaru ma dwie cechy specyficzne. Po pierwsze, 
zdecydowana większość badań dotyczy rynku amerykańskiego. Jeśli pominąć analizy efektywności pojedynczych placówek bankowych, wyjątkami od tej zasady w grupie cytowanych prac są tyko artykuły: M. Kima i B. Vale’a [2001] oparty na zbiorze danych z Norwegii, E. Bonaccorsi di Patti i G. Gobbiego [2001] wykorzystujący doświadczenia włoskie oraz P.S. Morrisona i R. O’Brien [2001] traktujący o rynku bankowym w Nowej Zelandii. Po drugie, duża intensyfikacja badań nad tworzeniem sieci bankowej i zmianami gęstości sieci na rynkach lokalnych nastąpiła przed uchwaleniem w 1994 r. przez amerykański Kongres ustawy Riegle'a-Neala liberalizującej zasady tworzenia sieci międzystanowych i w latach następujących po wdrożeniu tego aktu prawnego w życie.

Rezultaty badań nad wpływem regulacji w zakresie tworzenia i rozwoju sieci przez banki na procesy wzrostu gospodarczego są niejednoznaczne. R. Krol i S. Svorny [1996] na podstawie danych z lat 1970-1988 wykazują, że amerykańskie stany mające mniej restrykcyjne przepisy w zakresie ograniczania sieci bankowych cechowała lepsza dynamika dochodów ludności, produkcji i zatrudnienia. K.J. Mitchener i D. Wheelock [2013] na podstawie obserwacji z lat 1899-1929 także dla Stanów Zjednoczonych dowodzą zaś, że dla danego poziomu koncentracji zarówno wyższa liczba banków per capita, jak i większa liczba placówek miały pozytywny wpływ na wzrost produkcji w branżach wymagających zewnętrznego finansowania. $Z$ drugiej strony jednak istnieją prace kwestionujące występowanie jednoznacznego związku między rozwojem sieci banków a wzrostem gospodarczym. D.G. Freeman [2002] podważa podawane w niektórych innych źródłach oszacowania skali przyspieszenia wzrostu gospodarczego uzyskanego dzięki liberalizacji przepisów w zakresie tworzenia sieci placówek. Stwierdza on, że deregulacja była dokonywana przede wszystkim przez stany przeżywające kłopoty, co mogło spowodować zawyżenie ocen wpływu deregulacji na tempo wzrostu gospodarczego. W podobnym duchu wypowiada się R.R. Huang [2008], który badał efekty 23 wewnątrzstanowych deregulacji w zakresie tworzenia sieci z lat 1975-1990. Okazuje się, że tylko w pięciu przypadkach zanotowano statystycznie istotny pozytywny wpływ na stan lokalnej gospodarki.

Wejście wskutek deregulacji na rynki lokalne nowych konkurentów, zwykle dużych organizacji bankowych, w świetle dostępnych badań ma niekorzystny wpływ na dostęp do kredytu małych przedsiębiorstw. R. Zarutskie [2006] udokumentowała, że oddziaływanie wspomnianej powyżej ustawy Riegle’a-Neala zależało od okresu działania przedsiębiorstw. Nowo utworzone przedsiębiorstwa (pięcioletnie lub młodsze), cechujące się z punktu widzenia kapitałodawców największą asymetrią informacji, po deregulacji miały mniejszą skalę działalności i niższy udział zobowiązań w pasywach. W miarę wzrostu stopnia dojrzałości spółek opisany efekt zanikał. Przedsiębiorstwa 16-letnie lub starsze wykorzystywały po deregulacji więcej kapitału obcego i prowadziły szerzej zakrojone 
programy inwestycyjne. Podobne wnioski płyną z badań B. Hirtle [2007], która na podstawie danych z rynku amerykańskiego dowiodła, że placówki należące do sieci średniej wielkości w mniejszym stopniu kredytują małe przedsiębiorstwa niż placówki lokalnych banków. E. Bonaccorsi di Patti i G. Gobbi [2001] potwierdzili z kolei, że wejścia na rynek lokalny prowadzą do spadku dostępności kredytu dla małych przedsiębiorstw także we Włoszech.

Zwiększone możliwości rozwoju sieci sprzyjają obniżaniu ryzyka działalności banków. Przykładowo A.F. Shiers [2002] pokazuje na podstawie doświadczeń amerykańskich, że tworzenie sieci obniża wartość miar ryzyka opartych na zysku. C.D. Ramirez [2003], porównując prawdopodobieństwo upadłości banków w latach 1925-1929 w stanach, które dopuszczały tworzenie sieci, i w tych, które zabraniały tego rodzaju praktyk, dowodzi zaś, że restrykcyjne regulacje wpływały na większą częstość występowania bankructw. Obaj autorzy źródeł korzyści banków upatrują w dywersyfikacji lub możliwościach optymalizacji kosztów. Wspomniane korzyści doceniają uczestnicy rynków kapitałowych. D.R. Fraser i in. [1997] wykazali, że decyzja Office of Thrift Supervision z początku lat 90 . XX w., umożliwiająca amerykańskim instytucjom działającym na licencji federalnej tworzenie sieci międzystanowych, spotkała się z wyraźnie pozytywną reakcją inwestorów w przypadku dużych podmiotów, a w przypadku pozostałych była nieznacznie pozytywna lub neutralna. K.A. Carow i R.A. Heron [1998] stwierdzili natomiast, że w analizowanej przez nich próbie 180 amerykańskich holdingów bankowych ponadnormalna stopa dochodu w reakcji na zapowiedź zliberalizowania przepisów o tworzeniu sieci była dodatnia, statystycznie istotna i równa 2,2\%. Największe korzyści w zakresie wyceny rynkowej odnotowały przy tym banki mające typowe cechy celu przejęcia (niska rentowność, słabe wyposażenie kapitałowe) oraz banki działające w stanach, które przed 1994 r. miały najbardziej restrykcyjne przepisy w zakresie budowy sieci bankowych.

Ostatni ze zidentyfikowanych na początku tego punktu obszarów badawczych dotyczy kwestii sytuacji klienta korzystającego z usług depozytowo-rozliczeniowych. Zgodnie z oczekiwaniami literatura przedmiotu dostarcza argumentów na rzecz stwierdzenia, że rozwój sieci jest korzystny dla klientów. A.N. Berger, J.H. Leusner i J.J. Mingo [1997] pokazali, że banki mają tendencję do utrzymywania większej liczby placówek, niż wymaga tego cel minimalizacji kosztów. Nadmierna gęstość sieci jest, rzecz jasna, dobra z punktu widzenia konsumenta, ponieważ zwiększa jego wygodę. K. Ho i J. Ishii [2011] szacują ponadto, że przemiany w amerykańskim systemie bankowym, w tym głównie znoszenie ograniczeń w tworzeniu sieci w latach 1994-2000, dały korzyści rzędu 60 dolarów rocznie przeciętnemu gospodarstwu domowemu. W świetle dotychczasowych badań zyski z rozbudowy sieci nie dotyczą jednak wszystkich rynków i segmentów 
klientów. R.B. Avery i in. [1999] ustalili, że wskutek procesów konsolidacyjnych spadki liczby placówek były większe w regionach biedniejszych. P.S. Morrison i R. O'Brien [2001] dokumentują z kolei, że zamykanie placówek w regionach o niskim statusie socjoekonomicznym w Nowej Zelandii ma bardziej negatywne skutki dla ludności niż w innych regionach. Wejście na rynki lokalne dużych banków może także nieoczekiwanie prowadzić do zmniejszenia stóp oprocentowania depozytów. Dowodów na to, że tak się dzieje, dostarcza praca T.H. Hannana i R.A. Pragera [2004], którzy dowodzą, że banki sieciowe oferują niższe stopy oprocentowania niż lokalne, co przy ich dużym udziale w rynku lokalnym skutkuje obniżeniem oprocentowania również przez lokalne banki.

Wśród prac dotyczących placówek banków, do których udało się dotrzeć autorom, najbardziej zbliżony cel badawczy do obranego ma artykuł M. Huysentruyt, E. Lefevere i C. Menona [2013], którzy przeanalizowali dynamikę rozwoju sieci placówek na 233 rynkach lokalnych położonych na obszarze metropolitalnym Antwerpii. Okazało się, że w latach 1991-2006 zarówno dynamika wejść na rynki, jak i wyjść z nich uległa intensyfikacji, a wybór banków z punktu widzenia konsumenta pogorszył się. W podokresie 1991-1996 wejścia na rynek były pozytywnie skorelowane z udziałem obcokrajowców i starszych obywateli. Autorzy wyjaśniają to zjawisko chęcią poszerzenia bazy klientów przez banki. W podokresie 2001-2006 były natomiast dodatnio związane tylko z udziałem starszych osób, co autorzy tłumaczą wolniejszym przyswajaniem nowych technologii przez tę grupę klientów. Uzależnienie od dochodu, sytuacji ekonomicznej, występowało tylko w środkowym podokresie (1996-2001). Prawdopodobieństwo zamknięcia placówki było wtedy wyższe na obszarach biednych, a otwarcia nowej placówki wyższe na obszarach bogatych. Zidentyfikowana prawidłowość była nie tylko statystycznie istotna, ale także ekonomicznie znacząca.

\section{Hipotezy badawcze}

W badaniach testowano trzy hipotezy badawcze. Pierwsza z nich dotyczy gęstości sieci placówek, dwie kolejne dynamiki zmian gęstości. Wspomniane hipotezy są następujące:

- H1: gęstość sieci placówek jest większa na obszarach zamożnych i szybko się rozwijających,

- H2: banki koncentrują się na rozwoju sieci w regionach zamożnych i szybko rozwijających,

- H3: banki rozwijają sieć przede wszystkim na obszarach o niskiej dotychczasowej gęstości sieci placówek, ale dysponujących potencjałem wzrostowym. 
Zauważyć trzeba, że H2 przewiduje petryfikację istniejącej struktury dostępu do produktów i usług bankowych w Polsce, natomiast H3 wyrównywanie się łatwości dostępu.

\section{Dane i metoda badawcza}

W celu weryfikacji hipotez badawczych postawionych w artykule pozyskano od firmy Inteliace Research informacje o liczbie placówek w latach 2007-2013 w poszczególnych powiatach Polski w podziale na placówki SKOK, banków spółdzielczych oraz banków komercyjnych. W okresie badań najwyższą dynamiką wzrostu charakteryzowała się liczba placówek banków spółdzielczych, a najniższą - liczba placówek SKOK.

Tabela 1. Zmienne w modelu

\begin{tabular}{|c|c|}
\hline \multicolumn{2}{|r|}{ Wyszczególnienie } \\
\hline \multicolumn{2}{|c|}{ A. Nasycenie powiatów placówkami, przyrost liczby placówek (zmienne objaśniane) } \\
\hline PLAC & liczba placówek na 10 tys. mieszkańców \\
\hline WZR_PLAC & stopa wzrostu liczby placówek w powiecie w roku (pomnożona przez 100) \\
\hline \multicolumn{2}{|r|}{ B. Struktura placówek w powiecie } \\
\hline UDZIAL_SKOK & udział placówek SKOK-ów w łącznej liczbie placówek w powiecie \\
\hline$U D Z I A L \_B S$ & udział placówek banków spółdzielczych w łącznej liczbie placówek w powiecie \\
\hline \multicolumn{2}{|r|}{ C. Zamożność i aktywność ekonomiczna ludności } \\
\hline WYNAGR & przeciętne miesięczne wynagrodzenie brutto w relacji do średniej krajowej \\
\hline$B E Z R O B$ & stopa bezrobocia rejestrowanego \\
\hline FIZ_DZIAL & $\begin{array}{l}\text { osoby fizyczne prowadzące działalność gospodarczą na } 100 \text { osób w wieku } \\
\text { produkcyjnym }\end{array}$ \\
\hline NOWE_PODM & $\begin{array}{l}\text { nowo zarejestrowane podmioty gospodarki narodowej w roku na } 100 \text { miesz- } \\
\text { kańców }\end{array}$ \\
\hline INWEST & nakłady inwestycyjne w przedsiębiorstwach w tys. zł na mieszkańca \\
\hline \multicolumn{2}{|r|}{ D. Migracje ludności } \\
\hline$M I G R$ & saldo migracji w powiecie na 100 mieszkańców \\
\hline \multicolumn{2}{|r|}{ E. Poziom urbanizacji } \\
\hline$L U D N$ & liczba ludności w tys. na $1 \mathrm{~km}^{2}$ powierzchni \\
\hline
\end{tabular}

Źródło: opracowanie własne.

Informacje o liczbie placówek w powiatach zestawione zostały z danymi Głównego Urzędu Statystycznego charakteryzującymi poszczególne powiaty. Stworzony w ten sposób zestaw danych stanowił podstawę do oszacowania parametrów modeli panelowych, w których gęstość placówek w powiatach oraz stopa wzrostu 
liczby placówek w powiatach uzależniana była od charakterystyk powiatów. Zmienne zostały podzielone na grupy, przy czym z ostatecznego zestawu zmiennych wyeliminowano te, które w zbyt dużym stopniu skorelowane były z innymi potencjalnymi zmiennymi objaśniającymi. Ostatecznie użyty zestaw zmiennych przedstawia tabela 1.

$\mathrm{Z}$ uwagi na występowanie w zestawie danych względnie stałych charakterystyk powiatów na przestrzeni analizowanych lat estymowano modele panelowe $\mathrm{z}$ losowymi efektami indywidualnymi (random-effects). Budowane modele są natomiast dwojakiego rodzaju. Pierwszy zestaw modeli objaśnia gęstość sieci placówek na 10 tys. mieszkańców. W przypadku drugiego zestawu modeli zmienną objaśniającą jest z kolei stopa przyrostu liczby placówek. Tym samym szacowane modele będą dotyczyć bieżącego nasycenia powiatów placówkami, jak i tendencji zmian w tym zakresie, a więc pozwolą zweryfikować H1-H3. Ogólnie konstruowane modele opisują równania (1) i (2):

$$
\begin{gathered}
P L A C_{i t}=f\left(S T R_{i t-1}, Z^{\prime} A M_{i t-1}, M_{I G R_{i t-1}}, L U D N_{i t-1}, R_{t}\right), \\
W Z R_{-} P L A C_{i t}=f\left(P_{L A C_{i t-1}}, S T R_{i t-1}, Z A M_{i t-1}, M I G R_{i t-1}, L U D N_{i t-1}, R_{t}\right) .
\end{gathered}
$$

gdzie: $S T R_{i t-1}, Z A M_{i t-1}, M I G R_{i t-1}$ i $L U D N_{i t-1}$ określają odpowiednio: zestawy zmiennych z grup ,struktura placówek w powiecie”, ,zamożność i aktywność ekonomiczna ludności”, „migracje ludności” oraz „,poziom urbanizacji”. Z kolei $R_{t}$ oznacza zestaw zmiennych binarnych kodujących poszczególne lata objęte analizą. Zmienne $P L A C_{i t}$ oraz $W Z R_{-} P L A C_{i t}$ stworzone zostały zgodnie z definicją zawartą w tabeli 1 i odzwierciedlają odpowiednio liczbę placówek na 10 tys. mieszkańców oraz stopę wzrostu liczby placówek w powiecie w roku (pomnożoną przez 100).

W przypadku grupy „,zamożność i aktywność ekonomiczna ludności”, z uwagi na znaczący poziom korelacji między niektórymi zmiennymi z tej grupy, do każdego modelu włączono jedynie po trzy zmienne. W przypadku zmiennych odzwierciedlających strukturę placówek w powiecie testowano z kolei modele uwzględniające obie zmienne, jak też tylko tę, która pokazuje udział placówek SKOK. Budowa modelu bez uwzględnienia udziału placówek banków spółdzielczych wynika natomiast z faktu, że zmienna ta jest dość mocno ujemnie skorelowana z liczbą ludności przypadającą na $1 \mathrm{~km}^{2}$.

\section{Wyniki empiryczne}

W tabelach 2 oraz 3 przedstawiono wyniki oszacowania modeli panelowych zdefiniowanych w punkcie 4 . Modele te charakteryzują się satysfakcjonującą jakością. W obu grupach modeli wszystkie zmienne objaśniające są łącznie statystycznie istotne na poziomie niższym niż 0,01 . Warto jednak zaznaczyć, że dobroć 
dopasowania mierzona współczynnikiem $R^{2}$ jest znacznie lepsza dla modeli objaśniających liczbę placówek na 10 tys. mieszkańców niż dla modeli opisujących stopę wzrostu liczby placówek. W zależności od specyfikacji modelu indywidualnie statystycznie istotnych jest od czterech do pięciu zmiennych niezależnych.

Tabela 2. Oszacowania modeli panelowych objaśniających liczbę placówek na 10 tys. mieszkańców (PLAC)

\begin{tabular}{|c|c|c|c|c|c|c|}
\hline $\begin{array}{c}\text { Zmienna } \\
\text { niezależna }\end{array}$ & (1) & (2) & (3) & (4) & (5) & (6) \\
\hline$U D Z I A L \_B S$ & $\begin{array}{c}0,033 \\
(0,174)\end{array}$ & - & $\begin{array}{l}-0,044 \\
(0,175)\end{array}$ & - & $\begin{array}{l}-0,060 \\
(0,174)\end{array}$ & - \\
\hline UDZIAL_SKOK & $\begin{array}{c}-1,414 \text { *** } \\
(0,406)\end{array}$ & $\begin{array}{c}-1,419 * * * \\
(0,405)\end{array}$ & $\begin{array}{c}-1,521 * * * \\
(0,410)\end{array}$ & $\begin{array}{c}-1,515 * * * \\
(0,409)\end{array}$ & $\begin{array}{c}-1,513 * * * \\
(0,410)\end{array}$ & $\begin{array}{c}-1,504 * * * \\
(0,409)\end{array}$ \\
\hline WYNAGR & $\begin{array}{c}0,168 \\
(0,273)\end{array}$ & $\begin{array}{c}0,163 \\
(0,272)\end{array}$ & $\begin{array}{c}0,200 \\
(0,276)\end{array}$ & $\begin{array}{c}0,207 \\
(0,274)\end{array}$ & - & - \\
\hline BEZROB & $\begin{array}{l}-0,203 \\
(0,530)\end{array}$ & $\begin{array}{l}-0,204 \\
(0,530)\end{array}$ & $\begin{array}{l}-0,380 \\
(0,535)\end{array}$ & $\begin{array}{l}-0,378 \\
(0,535)\end{array}$ & $\begin{array}{l}-0,421 \\
(0,535)\end{array}$ & $\begin{array}{l}-0,419 \\
(0,535)\end{array}$ \\
\hline FIZ_DZIAL & $\begin{array}{c}0,078 * * * \\
(0,013)\end{array}$ & $\begin{array}{c}0,078 * * * \\
(0,013)\end{array}$ & - & - & - & - \\
\hline$N O W E \_P O D M$ & - & - & $\begin{array}{c}0,206 * * * \\
(0,078)\end{array}$ & $\begin{array}{c}0,207 * * * \\
(0,078)\end{array}$ & $\begin{array}{c}0,206 * * * \\
(0,078)\end{array}$ & $\begin{array}{c}0,207 * * * \\
(0,078)\end{array}$ \\
\hline INWEST & - & - & - & - & $\begin{array}{l}-0,001 \\
(0,005)\end{array}$ & $\begin{array}{l}-0,001 \\
(0,005)\end{array}$ \\
\hline$M I G R$ & $\begin{array}{c}-0,266 * * * \\
(0,071)\end{array}$ & $\begin{array}{c}-0,265 * * * \\
(0,071)\end{array}$ & $\begin{array}{c}-0,196 * * * \\
(0,070)\end{array}$ & $\begin{array}{c}-0,196 * * * \\
(0,070)\end{array}$ & $\begin{array}{c}-0,195 * * * \\
(0,070)\end{array}$ & $\begin{array}{c}-0,196 * * * \\
(0,070)\end{array}$ \\
\hline$L U D N$ & $\begin{array}{c}5,531 * * * \\
(0,083)\end{array}$ & $\begin{array}{c}5,526 * * * \\
(0,079)\end{array}$ & $\begin{array}{c}5,617 * * * \\
(0,082)\end{array}$ & $\begin{array}{c}5,624 * * * \\
(0,077)\end{array}$ & $\begin{array}{c}5,628 * * * \\
(0,081)\end{array}$ & $\begin{array}{c}5,639 * * * \\
(0,075)\end{array}$ \\
\hline Stała & $\begin{array}{c}-0,863 * * * \\
(0,301)\end{array}$ & $\begin{array}{c}-0,841 * * * \\
(0,278)\end{array}$ & $\begin{array}{l}-0,198 \\
(0,277)\end{array}$ & $\begin{array}{l}-0,225 \\
(0,256)\end{array}$ & $\begin{array}{l}-0,022 \\
(0,149)\end{array}$ & $\begin{array}{l}-0,051 \\
(0,123)\end{array}$ \\
\hline Obserwacje & 1516 & 1516 & 1516 & 1516 & 1516 & 1516 \\
\hline Test Walda & $6333 * * *$ & $6333 * * *$ & $6220 * * *$ & $6221 * * *$ & $6221 * * *$ & $6224 * * *$ \\
\hline$R^{2}$ & 0,809 & 0,809 & 0,806 & 0,806 & 0,806 & 0,806 \\
\hline
\end{tabular}

Uwagi: wszystkie modele uwzględniają zmienne binarne kodujące lata. W nawiasach podano błędy standardowe oszacowań. Symbole ***, **, * oznaczają, że możemy odrzucić hipotezę o zerowej wartości pojedynczych parametrów lub wszystkich oszacowanych parametrów łącznie odpowiednio na poziomie istotności: $0,01,0,05$ oraz 0,1 .

Źródło: opracowanie własne. 
W przypadku wszystkich modeli objaśniających gęstość placówek (tabela 2) można stwierdzić, że większe nasycenie placówkami odnotowywano w powiatach o dużej gęstości ludności na $1 \mathrm{~km}^{2}$. Innymi słowy, co nie jest zaskakujące, banki i SKOK-i miały względnie więcej placówek w rejonach bardziej zurbanizowanych. Ujemny i statystycznie istotny współczynnik przy zmiennej odzwierciedlającej saldo migracji (MIGR) sugeruje z kolei, że największe nasycenie placówkami nie występowało jednak w największych aglomeracjach, w których saldo to jest $\mathrm{z}$ reguły dodatnie.

Warto zwrócić uwagę na wyniki oszacowań dla zmiennych z grupy „zamożność i aktywność ekonomiczna ludności”. Statystycznie istotne i dodatnie współczynniki przy zmiennych $F I Z \_D Z I A L$ i $N O W E \_P O D M$ pozwalają stwierdzić, że najwięcej placówek występowało w rejonach, w których ludność była najaktywniejsza pod względem ekonomicznym. Współczynniki przy zmiennych BEZROB oraz WYNAGR nie są natomiast istotne statystycznie, ale mają oczekiwane znaki, tj. takie, które sugerują, że wyższa liczba placówek występowała w powiatach o niższej stopie bezrobocia i wyższym poziomie wynagrodzenia mieszkańców. Łącznie zatem zgromadzony materiał empiryczny przemawia umiarkowanie na korzyść H1.

Ostatnie ze spostrzeżeń wynikających z analizy tabeli 2 odnosi się do zmiennej odzwierciedlającej udział placówek SKOK w grupie wszystkich placówek w powiecie. Statystycznie istotny ujemny współczynnik przy tej zmiennej wynika z faktu, że w analizowanym okresie dynamika liczby placówek banków była wyższa niż dynamika liczby placówek SKOK. Tym samym przy wzroście liczby placówek banków i nieproporcjonalnym wzroście liczby placówek SKOK rosła gęstość placówek w ujęciu łącznym, ale malało znaczenie SKOK-ów na rynku lokalnym.

Analiza wyników oszacowania modeli objaśniających stopy wzrostu liczby placówek w powiatach (tabela 3) przynosi nowe spostrzeżenia. Statystycznie istotny (przy poziomie istotności 0,01 ) ujemny współczynnik przy opóźnionej zmiennej określającej gęstość placówek wskazuje na to, że banki lokowały nowe placówki przede wszystkim tam, gdzie do tej pory nasycenie nimi było mniejsze. Dodatkowo statystycznie istotne współczynniki przy trzech zmiennych z grupy „zamożność i aktywność ekonomiczna ludności” sugerują, że nowe placówki pojawiały się w rejonach o względnie niższym wynagrodzeniu, lecz stosunkowo wysokiej aktywności ekonomicznej ludności (zmienne FIZ_DZIAL i NOWE_PODM). Biorąc pod uwagę statystycznie istotny ujemny współczynnik przy zmiennej WYNAGR, jeszcze raz uzyskujemy potwierdzenie $\mathrm{H} 3$, że nowe placówki powstają tam, gdzie dotąd było ich mniej. O ile bowiem w modelach objaśniających gęstość placówek współczynnik przy zmiennej WYNAGR był dodatni, ale nieistotny statystycznie, o tyle w modelach dynamiki liczby placówek 
stopa wzrostu liczby placówek okazuje się statystycznie istotnie wyższa w tych powiatach, w których wynagrodzenia są przeciętnie niższe. Brak zatem argumentów na rzecz $\mathrm{H} 2$.

Tabela 3. Oszacowania modeli panelowych objaśniających stopę wzrostu liczby placówek (WZR_PLAC)

\begin{tabular}{|c|c|c|c|c|c|c|}
\hline $\begin{array}{c}\text { Zmienna } \\
\text { niezależna }\end{array}$ & (1) & (2) & (3) & (4) & (5) & (6) \\
\hline PLAC & $\begin{array}{c}-1,369 * * * \\
(0,243)\end{array}$ & $\begin{array}{c}-1,374 * * * \\
(0,234)\end{array}$ & $\begin{array}{c}-1,280 * * * \\
(0,237)\end{array}$ & $\begin{array}{c}-1,275 * * * \\
(0,226)\end{array}$ & $\begin{array}{c}-1,281 * * * \\
(0,239)\end{array}$ & $\begin{array}{c}-1,287 * * * \\
(0,226)\end{array}$ \\
\hline$U D Z I A L \_B S$ & $\begin{array}{c}0,212 \\
(1,533)\end{array}$ & - & $\begin{array}{l}-0,052 \\
(1,528)\end{array}$ & - & $\begin{array}{c}0,170 \\
(1,520)\end{array}$ & - \\
\hline UDZIAL_SKOK & $\begin{array}{c}7,559 * * \\
(3,855)\end{array}$ & $\begin{array}{c}7,347 * * \\
(3,574)\end{array}$ & $\begin{array}{l}7,141 * \\
(3,853)\end{array}$ & $\begin{array}{c}7,178 * * \\
(3,573)\end{array}$ & $\begin{array}{l}7,379 * \\
(3,865)\end{array}$ & $\begin{array}{c}7,208 * * \\
(3,584)\end{array}$ \\
\hline WYNAGR & $\begin{array}{c}-3,531 * \\
(2,028)\end{array}$ & $\begin{array}{c}-3,568 * \\
(2,011)\end{array}$ & $\begin{array}{c}-3,450 * \\
(2,027)\end{array}$ & $\begin{array}{c}-3,448 * \\
(2,009)\end{array}$ & - & - \\
\hline BEZROB & $\begin{array}{c}3,745 \\
(4,263)\end{array}$ & $\begin{array}{c}3,691 \\
(4,234)\end{array}$ & $\begin{array}{c}1,788 \\
(4,312)\end{array}$ & $\begin{array}{c}1,800 \\
(4,302)\end{array}$ & $\begin{array}{c}2,403 \\
(4,274)\end{array}$ & $\begin{array}{c}2,405 \\
(4,268)\end{array}$ \\
\hline$F I Z \_D Z I A L$ & $\begin{array}{c}0,301 * * * \\
(0,111)\end{array}$ & $\begin{array}{c}0,295 * * * \\
(0,103)\end{array}$ & - & - & - & - \\
\hline NOWE_PODM & - & $\begin{array}{l}- \\
- \\
* *\end{array}$ & $\begin{array}{c}2,718 * * \\
(1,181)\end{array}$ & $\begin{array}{c}2,729 * * \\
(1,096)\end{array}$ & $\begin{array}{c}2,762 * * \\
(1,184)\end{array}$ & $\begin{array}{c}2,710 * * \\
(1,098)\end{array}$ \\
\hline INWEST & - & - & - & - & $\begin{array}{l}-0,129 \\
(0,095)\end{array}$ & $\begin{array}{l}-0,129 \\
(0,095)\end{array}$ \\
\hline$M I G R$ & $\begin{array}{c}-1,722 * * \\
(0,722)\end{array}$ & $\begin{array}{l}-1,710 \\
(0,720)\end{array}$ & $\begin{array}{c}-1,587 * * \\
(0,723)\end{array}$ & $\begin{array}{c}-1,585 * * \\
(0,721)\end{array}$ & $\begin{array}{c}-1,597 * * \\
(0,725)\end{array}$ & $\begin{array}{c}-1,589 * * \\
(0,722)\end{array}$ \\
\hline$L U D N$ & $\begin{array}{r}-0,297 \\
(0,414)\end{array}$ & $\begin{array}{l}-0,314 \\
(0,397)\end{array}$ & $\begin{array}{l}-0,325 \\
(0,417)\end{array}$ & $\begin{array}{l}-0,323 \\
(0,402)\end{array}$ & $\begin{array}{l}-0,408 \\
(0,415)\end{array}$ & $\begin{array}{l}-0,423 \\
(0,398)\end{array}$ \\
\hline Stała & $\begin{array}{c}10,271 * * * \\
(2,674)\end{array}$ & $\begin{array}{c}10,506 * * * \\
(2,058)\end{array}$ & $\begin{array}{c}11,351 * * * \\
(2,568)\end{array}$ & $\begin{array}{c}11,293 * * * \\
(2,003)\end{array}$ & $\begin{array}{c}8,616 * * * \\
(1,924)\end{array}$ & $\begin{array}{c}8,768 * * * \\
(1,304)\end{array}$ \\
\hline Obserwacje & 1516 & 1516 & 1516 & 1516 & 1516 & 1516 \\
\hline Test Walda & $69,63 * * *$ & $69,64 * * *$ & $67,47 * * *$ & $67,52 * * *$ & $66,36 * * *$ & $66,39 * * *$ \\
\hline$R^{2}$ & 0,090 & 0,090 & 0,088 & 0,088 & 0,088 & 0,088 \\
\hline
\end{tabular}

Uwagi: wszystkie uwzględniają zmienne binarne kodujące lata. W nawiasach podano błędy standardowe oszacowań. Symbole ***, **, * oznaczają, że możemy odrzucić hipotezę o zerowej wartości pojedynczych parametrów lub wszystkich oszacowanych parametrów łącznie odpowiednio na poziomie istotności: $0,01,0,05$ oraz 0,1 .

Źródło: opracowanie własne. 
Dodatkowych informacji o charakterystyce powiatów, w których stopa wzrostu liczby placówek była względnie wyższa, dostarczają statystycznie istotne współczynniki przy zmiennych MIGR oraz UDZIAL_SKOK. Ujemny współczynnik przy pierwszej ze zmiennych wskazuje na to, że placówki lokowano tam, skąd odpływała ludność. Można domniemywać, że były to mniejsze miasta i wsie, zwłaszcza że współczynnik przy zmiennej $L U D N$ jest ujemny, choć nieistotny statystycznie. Dodatni współczynnik przy zmiennej UDZIAL_SKOK w połączeniu z informacją o wyższej stopie wzrostu liczby placówek banków względem stopy wzrostu liczby placówek SKOK pozwala z kolei stwierdzić, że wzrost liczby placówek w ujęciu łącznym mógł wynikać z wypierania SKOK-ów z rynku przez banki w miejscach, w których SKOK-i miały dotąd względnie mocną pozycję.

\section{Uwagi końcowe}

Podsumowując wyniki oszacowań modeli panelowych, należy stwierdzić, że w latach 2007-2013 stopa wzrostu liczby placówek banków i SKOK okazała się wyższa w powiatach, w których dotychczas obserwowano niższe zagęszczenie placówek. Były to przy tym powiaty o przeciętnie niższym średnim wynagrodzeniu i dotychczas względnie wyższym udziale SKOK-ów. Rezultaty analiz pokazują ponadto z jednej strony, że zagęszczenie placówek wciąż jest największe na terenach bogatszych i bardziej zurbanizowanych, z drugiej zaś, że najwyższe przyrosty liczby placówek zaznaczają się w rejonach o specyfice mniejszych miast i wsi. Wspiera to hipotezę o występowaniu zjawiska wyrównywania poziomu nasycenia powiatów placówkami w latach 2007-2012. Z innych czynników ekonomicznych determinujących lokalizację nowych placówek warto wspomnieć o aktywności ekonomicznej ludności, która wpływa dodatnio zarówno na gęstość placówek, jak i stopę wzrostu liczby placówek.

Uzyskane wyniki, jak łatwo zauważyć, odbiegają od tych prezentowanych przez M. Huysentruyt, E. Lefevere i C. Menona [2013]. Przyczyn różnic należy upatrywać, zdaniem autorów, w odmiennym stopniu rozwoju rynku usług bankowych w Polsce i Belgii. Zaobserwowany w niniejszych badaniach rozwój sieci placówek w regionach uboższych, dotychczas upośledzonych, jest bez wątpienia zjawiskiem korzystnym ze względu na dostęp klientów do produktów i usług bankowych. Wpływ tego rozwoju na dostęp do kredytu małych przedsiębiorstw i stopy oprocentowania depozytów nie są jednak w świetle ustaleń empirycznych przytoczonych w punkcie 2 już tak oczywiste. Zbadanie wpływu rozwoju sieci na dostęp do kredytu lokalnych przedsiębiorstw wykracza poza ramy prezentowanego opracowania i stanowić będzie kolejny etap badań. 


\section{Literatura}

Avery R.B., Bostic R.W., Calem P.S., Canner G.B. [1999], Consolidation and Bank Branching Patterns, ,Journal of Banking and Finance”, vol. 23, http://dx.doi.org/10.1016/ S0378-4266(98)00094-6.

Berger A.N., Leusner J.H., Mingo J.J. [1997], The Efficiency of Bank Branches, „Journal of Monetary Economics", vol. 40, http://dx.doi.org/10.1016/S0304-3932(97)00035-4.

Bonaccorsi di Patti E., Gobbi G. [2001], The Changing Structure of Local Credit Markets: Are Small Businesses Special?, ,Journal of Banking and Finance”, vol. 25, http:// dx.doi.org/10.1016/S0378-4266(01)00191-1.

Carow K.A., Heron R.A. [1998], The Interstate Banking and Branching Efficiency Act of 1994: A Wealth Event for Acquisition Targets, „Journal of Banking and Finance”, vol. 22, http://dx.doi.org/10.1016/S0378-4266(97)00052-6.

Fraser D.R., Hooton J.L., Kolari J.W., Reising J.J. [1997], The Wealth Effects of Interstate Branching, ,Journal of Banking and Finance”, vol. 21, http://dx.doi.org/10.1016/S03784266(96)00056-8.

Freeman D.G [2002], Did State Bank Branching Deregulation Produce Large Growth Effects? „Economic Letters”, vol. 75.

Hannan T.H., Prager R.A. [2004], The Competitive Implications of Multimarket Bank Branching, ,Journal of Banking and Finance”, vol. 28, http://dx.doi.org/10.1016/j. jbankfin.2003.06.006.

Hirtle B. [2007], The Impact of Network Size on Bank Branch Performance, ,Journal of Banking and Finance", vol. 31, http://dx.doi.org/10.1016/j.jbankfin.2007.01.020.

Ho K., Ishii J. [2011], Location and Competition in Retail Banking, „International Journal of Industrial Organization", vol. 29, http://dx.doi.org/10.1016/j.ijindorg.2010.11.004.

Huang R.R. [2008], Evaluating the Real Effect of Bank Branching Deregulation: Comparing Contiguous Counties across US State Borders, ,Journal of Financial Economics”, vol. 87, http://dx.doi.org/10.1016/j.jfineco.2007.01.004.

Huysentruyt M., Lefevere E., Menon C. [2013], Dynamics of Retail-bank Branching in Antwerp (Belgium) 1991-2006: Evidence from Micro-geographic Data, ,Journal of Banking and Finance", vol. 37, http://dx.doi.org/10.1016/j.jbankfin.2012.08.23.

Kim M., Vale B. [2001], Non-price Strategic Behavior: The Case of Bank Branches, „International Journal of Industrial Organization”, vol. 19, http://dx.doi.org/10.1016/ S0167-7187(00)00064-3.

Krol R., Svorny S. [1996], The Effect of the Bank Regulatory Environment on State Economic Activity, „Regional Science and Urban Economics”, vol. 26, http://dx.doi. org/10.1016/0166-0462(96)02129-1.

Mitchener K.J., Wheelock D. [2013], Does the Structure of Banking Markets Affect Growth? Evidence from U.S. State Banking Markets, ,Explorations in Economic History”, vol. 50, http://dx.doi.org/10.1016/j.eeh.2012.09.004.

Morrison P.S., O'Brien R. [2001], Bank Branches Closures in New Zealand: The Application of a Spatial Interaction Model, „Applied Geography”, vol. 21, http://dx.doi. org/10.1016/S0143-6228(01)00014-5.

Ramirez C.D. [2003], Did Branch Banking Restrictions Increase Bank Failures? Evidence from Virginia and West Virginia in the Late 1920s, „Journal of Economics and Business", vol. 55. 
Shiers A.F. [2002], Branch Banking, Economic Diversity and Bank Risk, „The Quarterly Review of Economics and Finance", vol. 42.

Zarutskie R. [2006], Evidence on the Effects of Bank Competition on Firm Borrowing and Investment, ,,Journal of Financial Economics”, vol. 81, http://dx.doi.org/10.1016/ j.jfineco.2005.07.008.

\section{Features of Local Markets and Banks' Decisions on Outlet Networks}

This paper investigates how local market features influence the decisions taken by Polish banks regarding their branch networks. It was found that during the period 20072013 the density of branch networks was highest in relatively rich and urbanized regions. However, the rate of growth in the number of branches was more rapid in regions whose density of branches had hitherto been lower. It was found, moreover, that the presence of an entrepreneurial population had a positive impact on both the density and growth rate of branches.

Keywords: local markets, branch networks, competition, banks. 